\title{
Introduction of the Danube Delta Database
}

Jenica Hanganu, Ion Navodaru, Iuliana Mihaela Tudor, Orhan Ibram, Mihai Doroftei \& Aurel Nastase
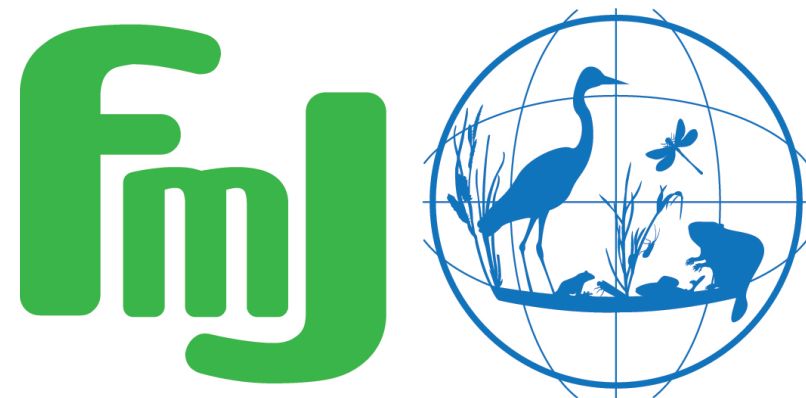

Freshwater Metadata Journal 



\title{
Introduction of the Danube Delta Database
}

\author{
Jenica Hanganu ${ }^{1}$, Ion Navodaru ${ }^{1}$, Iuliana Mihaela Tudor ${ }^{1}$, Orhan Ibram ${ }^{1}$, Mihai Doroftei ${ }^{1}$ \& \\ Aurel Nastase ${ }^{1}$ \\ 1 Danube Delta National Institute for Research and Development, Tulcea, Romania; corresponding author: jenica.hanganu@ddni.ro
}

Please cite this paper as follows: Hanganu J., Navodaru I., Tudor I. M., Ibram O., Doroftei M. \& Nastase A., 2015. Introduction of the Danube Delta Database. Freshwater Metadata Journal 8: 1-11.

http://dx.doi.org/10.15504/fmj.2015.8

Received: 2015-05-13 / Published: 2015-07-22

\section{Keywords}

Danube delta, aquatic macrophytes, fish, zoo-plankton, macro-invertebrates

\section{Short description of the dataset/summary}

A description of biological and ecological data of the Danube delta lakes and channels is presented. The biological indicators refer to aquatic macrophytes, fish, zoo-plankton, and macro-invertebrates. Environmental data include physio-chemical data as well as hydrological parameters.

\section{General information}

dataset entry ID:

name of the dataset:

full name of the dataset:

dataset short name:

type of dataset:

data type:
MARS_12

Metadata of the Danube Delta Database

DELTA

species (taxonomic group) per site database including environmental information

point data/observation data

science keywords according to GCMD:

topic:

keywords:
Biosphere, Biological Classification, Terrestrial Hydrosphere

Danube delta , aquatic macrophytes, fish, zoo- plankton, macro-invertebrate

ISO topic category according to ISO 19115:

Biota, Environment, Inland Waters 


\section{Technical and administrative specifications}

$\begin{array}{ll}\text { data format: } & \text { Excel } \\ \text { operating system: } & \text { all Windows systems } \\ \text { data language: } & \text { English } \\ \text { current access level: } & \text { restricted access, internal } \\ \text { currently available through GBIF: } & \text { no } \\ \quad \text { exchange planned: } & \text { no } \\ \text { update level: } & \text { continously updated } \\ \text { documentation: } & \\ \quad \text { type: } & \text { internal description } \\ \quad \text { language: } & \text { English }\end{array}$

\section{Do you plan to publish the data on the BioFresh data portal:}

contact details:

no

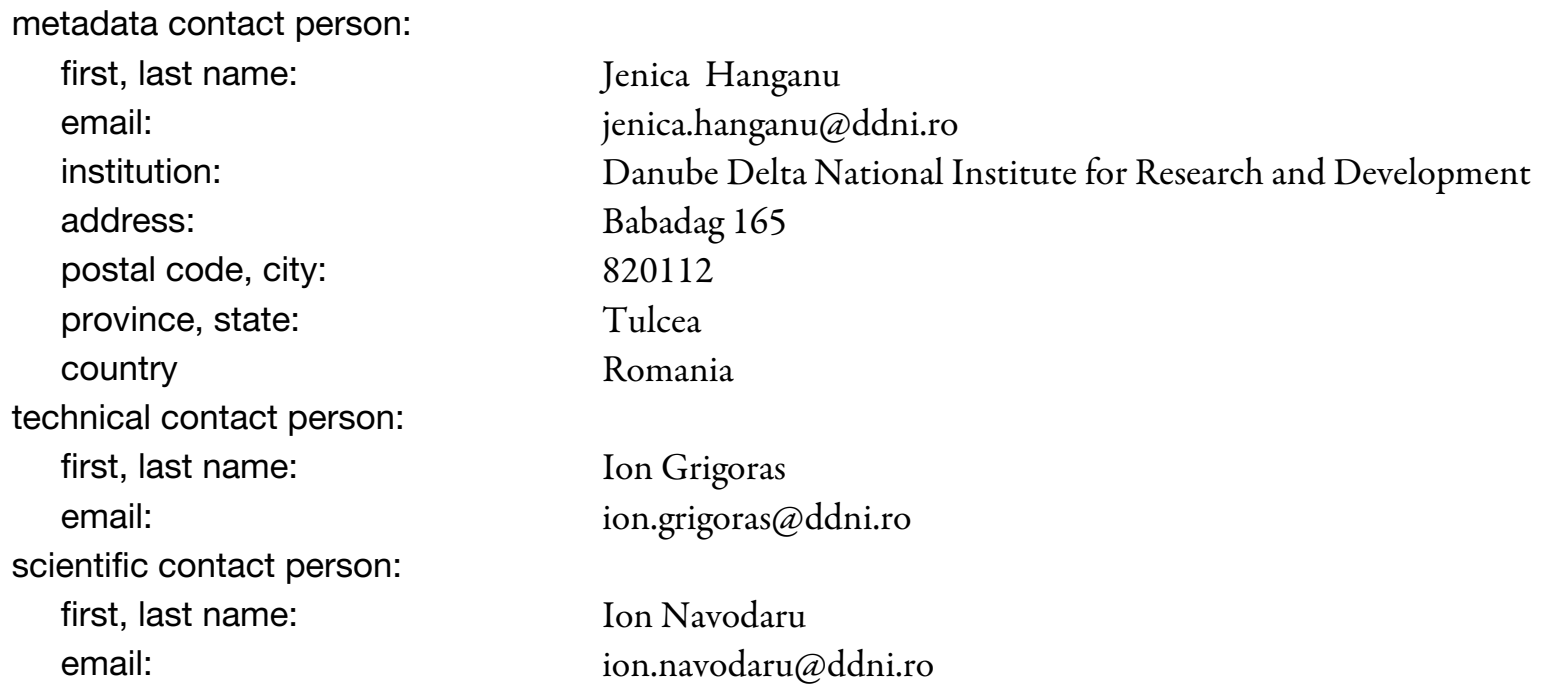

\section{Intellectual property rights and citation}

dataset creator (data compiler):

contact name:

Jenica Hanganu

contact email:

jenica.hanganu@ddni.ro

contact institution:

Danube Delta National Institute for Research and Development

data contributors to/owners of this dataset:

number:

multiple

data contributor/owner 1:

contact name:

4

contact email:

Ion Navodaru, Aurel Nastase

contact institute:

ion.navodaru@ddni.ro

criteria for using this part of the dataset:

Danube Delta National Institute for Research and Development

The dataset needs to be requested from dataset creator with specific conditions of use.

comments:

Fish database

data contributor/owner 2:
contact name:
Iuliana Mihaela Tudor
contact email:
mihaela.tudor@ddni.ro 
contact institute:

criteria for using this part of the dataset:

Danube Delta National Institute for Research and Development

The dataset needs to be requested from dataset creator with specific conditions of use.

comments:

Zoo-plankton database

data contributor/owner 3:

contact name:

Orhan Ibram

contact email:

orhan.ibram@ddni.ro

contact institute:

Danube Delta National Institute for Research and Development

criteria for using this part of the dataset:

The dataset needs to be requested from dataset creator with specific conditions of use.

comments:

Macro-invertebrates database

\section{data contributor/owner 4:}

contact name:

contact email:

Jenica Hanganu, Mihai Doroftei

contact institute:

jenica.hanganu@ddni.ro,mihai.doroftei@ddni.ro

criteria for using this part of the dataset:

The dataset needs to be requested from dataset creator with specific conditions of use.

comments:

Aquatic macrophytes database

citation of this dataset:

author(s):

Hanganu J., Navodaru I., Tudor I. M., Ibram O., Doroftei M., \& Nastase A.

title:

Danube Delta database

year:

2014

citation of the metadata:

author(s):

Hanganu J., Navodaru I., Tudor I. M., Ibram O., Doroftei M., \& Nastase A. title and journal (name, number, pages):

Introduction of the Danube Delta Database. Freshwater Metadata Journal 8:

$1-11$

year: $\quad 2015$

doi: $\quad$ http://dx.doi.org/10.15504/fmj.2015.8

\section{General data specifications}

regional coverage of the dataset:

scale of the dataset: regional

spatial extend (bounding coordinates):

southernmost latitude $\left[{ }^{\circ}\right]$ :

$44^{\circ} 20^{\prime} 56.16^{\prime \prime}$

northernmost latitude $\left[^{\circ}\right]$ :

$45^{\circ} 26^{\prime} 57.30^{\prime \prime}$

westernmost longitude $\left[{ }^{\circ}\right]$ :

$28^{\circ} 28^{\prime} 51.10^{\prime \prime}$

easternmost longitude $\left[{ }^{\circ}\right]$ :

$29^{\circ} 49^{\prime} 37.16^{\prime \prime}$

minimum altitude:

0.0 metres

maximum altitude:

47 metres

countries:

Europe: Romania

comments:

Danube Delta Biosphere Reserve - Romania

world climatic regions according to Köppen:

Group D: continental/microthermal climate

freshwater ecoregions of the world (FEOW) according to WWF:

Europe: Dniester - Lower Danube 


\section{European ecoregions according to Illies (WFD):}

Pontic Province (ER12)

ecosystem type:

covered timeframe: rivers, lakes/ponds, wetlands, coastal areas

$2000-2014$

\section{Site specifications}

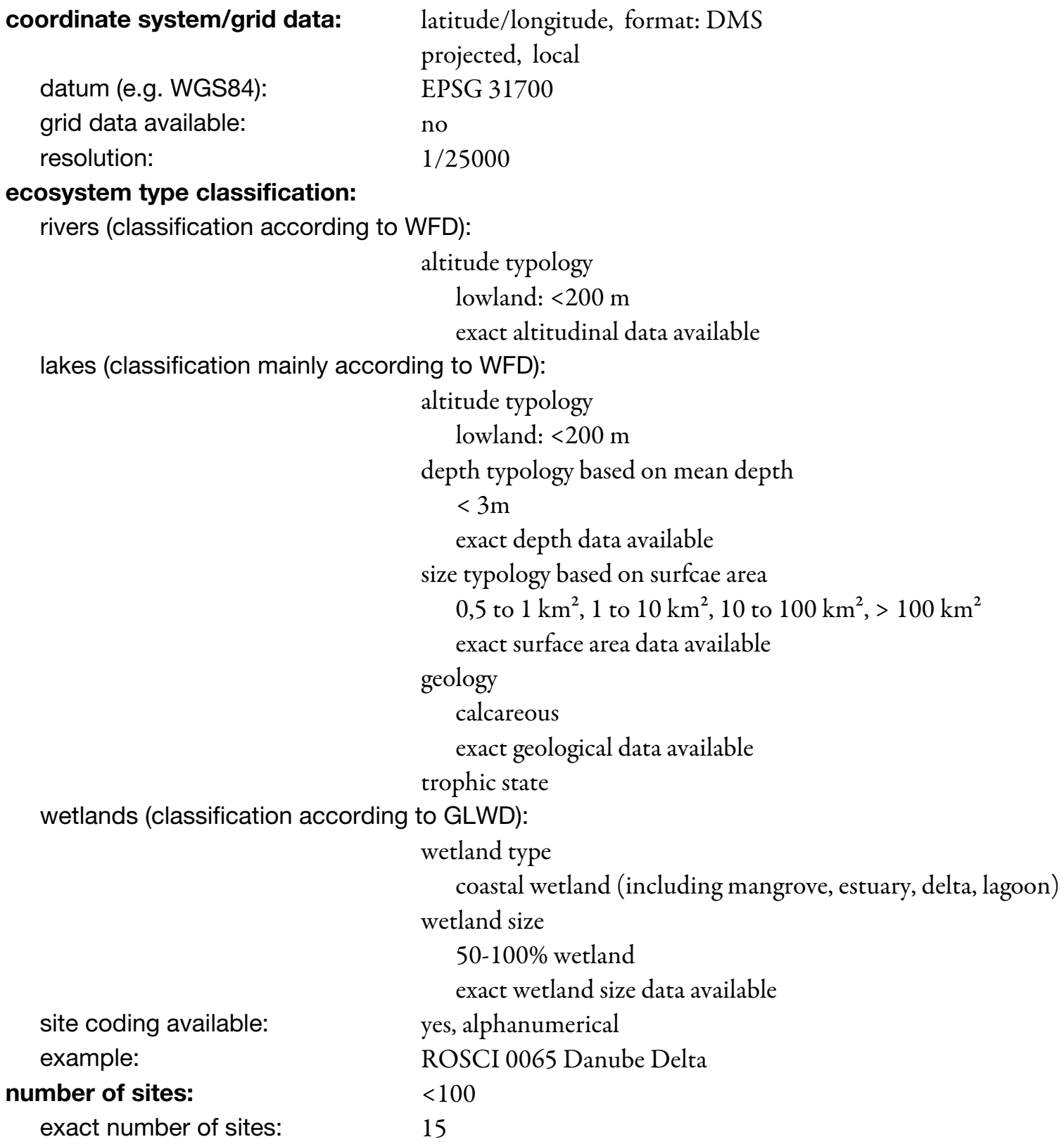

\section{Climate and environmental data}

\section{climate related data:}

spatial resolution of the data (if not catchment/site related):

$50 \mathrm{~km}$

available parameters per catchment:

mean annual temperature January, July

data source: http://www.meteoromania.ro/anm/?page_id=138 


\section{environmental data:}

mean annual temperature for each month

data source: http://www.meteoromania.ro/anm/?page_id=138

minimal, maximal and mean winter and summer temperatures data source: http://www.meteoromania.ro/anm/?page_id=138

daily air temperatures

data source: http://www.meteoromania.ro/anm/?page_id=138

mean annual precipitation

data source: http://www.meteoromania.ro/anm/?page_id=138

winter and summer precipitation

data source: http://www.meteoromania.ro/anm/?page_id=138

evaporation

data source: http://www.meteoromania.ro/anm/?page_id=138

mean discharge

data source: http://www.meteoromania.ro/anm/?page_id=138

available parameters per catchment:

catchment size

data source: http://www.icpdr.org/main/danube-basin

catchment land cover/land use

data source: GIO Land Monitoring 2011-2013 in the framework of regulation (EU) No $911 / 2010$

hydrological regime/flow regime

data source: Sobek rural 1D/2D for the lower Danube and Danube delta

available parameters per site: catchment land use upstream of sampling site

data source: GIO Land Monitoring 2011-2013 in the framework of regulation (EU) No $911 / 2010$

catchment land use along a buffer strip (100m width on both sides) upstream

$(10 \mathrm{~km})$ of the sampling site

data source: GIO Land Monitoring 2011-2013 in the framework of regulation (EU) No $911 / 2010$

information on floodplain inundation duration

data source: Sobek rural 1D/2D for the lower Danube and Danube delta information on riparian vegetation (incl. information on modification)

data source: Hanganu J. et. al., 2002

information on embankment (incl. information on modification)

data source: DTM of the Danube delta and Danube river

information on channel form (incl. information on modification)

data source: DTM of the Danube delta and Danube river

information on cross section (incl. information on modification)

data source: Sobek rural 1D/2D for the lower Danube and Danube delta

distance to next migration barrier upstream

data source: DTM of the Danube delta and Danube river

distance to the next lake upstream

data source: DTM of the Danube delta and Danube river

distance to the next main village/town upstream

data source: DTM of the Danube delta and Danube river

river length

data source: http://www.icpdr.org/main/danube-basin

distance to source

data source: http://www.icpdr.org/main/danube-basin

distance to mouth 
comments:

physico-chemistry data:

data source: http://www.icpdr.org/main/danube-basin stream order (according to Strahler)

data source: DTM of the Danube delta and Danube river slope

data source: DTM of the Danube delta and Danube river hydrological regime/flow regime

data source: Sobek rural 1D/2D for the lower Danube and Danube delta discharge

data source: Sobek rural 1D/2D for the lower Danube and Danube delta current velocity

data source: Sobek rural 1D/2D for the lower Danube and Danube delta maximum depth

data source: Sobek rural 1D/2D for the lower Danube and Danube delta mean depth

data source: Sobek rural 1D/2D for the lower Danube and Danube delta information on instream habitat (incl. information on modification)

Hanganu, J., Dubyna, D., Zhmud, E., Grigoras, I., Menke, U., Drost, H., Stefan, N., \& Sârbu, I. (2002). Vegetation of the Biosphere Reserve "Danube Delta" with Transboundary Vegetation Map on a 1: 150000 scale. Danube Delta National Institute, Romania; M.C. Kholodny - Institute of Botany \& Danube Delta

Biosphere Reserve, Ukraine and RIZA The Netherlands. RIZA Rapport 2002049, Lelystadt.

total $\mathrm{P}$, ortho $\mathrm{P}$, total dissolved $\mathrm{P}$, nitrate, nitrite, total $\mathrm{N}$, ammonium, sulphate, chloride, sodium, magnesium, calcium, alkalinity, TOC (total organic carbon), oxygen content, BOD5 (biochemical oyxgen demand), water temperature, $\mathrm{pH}$, conductivity, chlorophyll, Secci disc depth, suspended solids, substrate, sediment/soil parameters

availability of physico-chemical data, if there is more than one sample per site: mean values per site

comments:

stressors influencing the sites:

reference sites available: 


\begin{tabular}{|l|l|l|l|l|}
\hline stressor & $\begin{array}{l}\text { restored sites } \\
\text { available }\end{array}$ & $\begin{array}{l}\text { data before/after } \\
\text { restoration } \\
\text { available }\end{array}$ & $\begin{array}{l}\text { stressor gradient } \\
\text { available }\end{array}$ & comments \\
\hline eutrophication & yes & yes & no & \\
\hline $\begin{array}{l}\text { hydromorphological } \\
\text { degradation }\end{array}$ & yes & yes & no & \\
\hline $\begin{array}{l}\text { hydrologic stress } \\
\text { (e.g. impoundment, } \\
\text { flow velocity } \\
\text { reduction, } \\
\text { hydropeaking, water } \\
\text { abstraction, flow } \\
\text { velocity increase) }\end{array}$ & yes & yes & yes & \\
\hline
\end{tabular}

\section{Biological data}

biological data origin:

specify project:

organism group addressed: from sampling

Danube delta monitoring programm and other national and international collaboratives projects

fish, macro-invertebrates (Mollusca, Ephemeroptera, Odonata, Coleoptera, Trichoptera, Chironomidae), zooplankton, macrophytes

\section{Sample specifications/sample resolution}

\section{fish:}

\section{sample information:}

covered timeframe:

$1996-2014$

historical data:

no

palaeo data:

no

season:

spring, summer, autumn

temporal resolution/frequency of sampling:

time series data:

per season and/or per year

\section{taxonomic resolution:}

level:

percentage of species level data:

no

\section{taxonomic coding:}

taxalist according to: reference(s):

coding system:

example:

sample specifications:

type: family, genus, species

100

Kotelat \& Freyhof 2007

Kottelat M. and J. Freyhof 2007. European Freshwater Fishes. Kottelat, Cornol, Switzerland and Freyhof, Berlin, Germany. 646p. ISBN 978-2-8399-0298-4.

Banarescu P., 1964. Pisces Osteichthyes. Fauna Republicii Populare Romane.

Bucuresti, 963p.

Froese, R. and D. Pauly. Editors. 2015. FishBase. World Wide Web electronic publication. www.fishbase.org, version (04/2015).

no number coding system for taxa

genus \& species: Esox lucius

quantitative (abundance data) 
number of samples:

500

specification of method(s) used for sampling and sorting:

scientific fishing with: research seine, commercial gillnets, nordic gillnets, electric fishing

reference(s):

CEN, 2005. Water quality - Sampling of Fish with multi-mesh gillnets. EN 14757:2005:E.

CEN, 2003. Water quality - Sampling of fish with electricity. EN 14011:2003:E. sample type (e.g. habitat specific samples, composite samples etc.):

composite samples

specific sample location (e.g. littoral, profundal, transect, shoreline, hyporheic zone, etc.):

large rivers, canals, shallow lakes, littoral sea

other important sample related informations:

relative abundance and biomass data (Catch per Unit Fishing Effort - CPUE)

\section{macro-invertebrates:}

\section{sample information:}

covered timeframe:

$2000-2014$

historical data:

no

palaeo data:

no

season:

spring, summer, autumn

temporal resolution/frequency of sampling:

minimum 3/year

time series data:

no

\section{taxonomic resolution:}

level:

family, genus, species

percentage of species level data: 100

\section{taxonomic coding:}

taxalist according to:

reference(s):

\section{Fauna Europaea}

de Jong, Y.S.D.M. (ed.) (2013) Fauna Europaea version 2.6. Web Service available online at http://www.faunaeur.org

\section{sample specifications:}

type:

replicate samples:

quantitative (abundance data), semi-quantitative

number of samples:

no

700

specification of method(s) used for sampling and sorting:

Sampling with Ekman-Birge grab and hand-net; samples sieved with 500 micrometer mesh size; samples preserved in $70 \%$ ethanol.

reference(s):

ISO 10870: 2012-10 Water quality - Guidelines for the selection of sampling methods and devices for benthic macroinvertebrates in fresh waters

sample type (e.g. habitat specific samples, composite samples etc.):

composite sample

specific sample location (e.g. littoral, profundal, transect, shoreline, hyporheic zone, etc.):

\section{zooplankton:}

shallow lakes and channels

\section{sample information:}

covered timeframe:

$2000-2014$

historical data:

no

palaeo data:

no

season:

spring, summer, autumn

temporal resolution/frequency of sampling:

minimum 3/year 
time series data:

\section{taxonomic resolution:}

level:

\section{taxonomic coding:}

taxalist according to:

reference(s):

\section{sample specifications:}

type:

no percentage of species level data: 100

number of samples:

family, genus, species

Fauna Europaea

de Jong, Y.S.D.M. (ed.) (2013) Fauna Europaea version 2.6. Web Service available online at http://www.faunaeur.org

quantitative (abundance data), qualitative

1000

specification of method(s) used for sampling and sorting:

The frequency and location of zooplankton sampling is dictated by the purpose of the study. Locate sampling stations as near as possible to those selected for phytoplankton, benthic organisms and physical-chemical sampling. Surface water samples were collected from the lakes in five stations per lake and three stations per Danube branch stations.

Zooplankton is collected by filtering 30 liters of water from the surface of the water body through plankton net $(55 \mu \mathrm{m}$ mesh size) and fixed immediately with absolute ethanol, into plastic container.

Sedimentation is the preferred method of concentration because it is non-selective and non-destructive (unlike filtration or centrifugation which can damage many of the rotiferans and cladocera species).

From each sample $1 \mathrm{ml}$ sub-sample is placed in a Sedgwick-Rafter counting cell for identification and enumeration under optical microscope at $20 \mathrm{X}$ to $40 \mathrm{X}$ magnification. From each sample, depending on sample location and concentration 1-4 $\mathrm{ml}$ sub-samples were analyzed.

reference(s): $\quad$ Clesceri L. S., Greenberg A. E., Trussell R. R., (ed.) Crumpton W. G., Murray A. P., Paterson R. A., Sellner K. G., Suidan M. T., Sullivan B. F., Swartz R., Sweeney R. A. \& Walsh G. E. (1989) Biological examination of water. Part 10000, Standard Methods for the examination of water and waste water 17 th Edition. Washington American Public Health Association: 10-194

sample type (e.g. habitat specific samples, composite samples etc.): composite samples

specific sample location (e.g. littoral, profundal, transect, shoreline, hyporheic zone, etc.):

transect

\section{macrophytes:}

\section{sample information:}

covered timeframe:

$1996-2014$

historical data:

no

palaeo data:

no

season:

spring, summer, autumn

temporal resolution/frequency of sampling:

time series data:

per year

no

\section{taxonomic resolution:}

level:

order, family, sub-family, genus, species

percentage of species level data: 100

\section{taxonomic coding:}

taxalist according to:

Flora Europaea 
reference(s):

coding system:

example:

sample specifications:

type:

replicate samples:

number of samples:
http://en.wikipedia.org/wiki/Flora_Europaea

Natura 2000; EU-code

1428, Marsilea quadrifolia

quantitative (abundance data), qualitative, presence/absence

no

700

specification of method(s) used for sampling and sorting:

The Kohler survey method. During visits of the lakes by canoe a varying number of relevees per lake was sampled, depending on lake size, allocated time, observed variation in the vegetation.

Each relevee had a diameter of c. $5 \mathrm{~m}$; total plant cover, and cover of individual plant species and filamentous algae were established using both visual observation and by rake operation. For each species the percentage cover projected at the bottom was estimated using a 5-point scale.

reference(s):

Kohler, A. (1978): Methoden der Kartierung von Flora und Vegetation von Süßwasserbiotopen. Landschaft + Stadt 10 (2): 73-85.

sample type (e.g. habitat specific samples, composite samples etc.):

habitat specific samples

specific sample location (e.g. littoral, profundal, transect, shoreline, hyporheic zone, etc.):

transect

other important sample related informations:

Environmental factors considered were: depth (m), lake size (ha), amplitude

(m) cumulative residence time (days), soil organic matter content (\%), and soil clay fraction (\%).

The lakes were ordinated along Principal Component axes (PCA, in CANOCO, Ter Braak, 1991).

The main ordination shows three directions: 1) clear mineral lakes with a dense vegetation; 2) turbid mineral lakes with a sparse vegetation; 3 ) isolated plaur lakes.

\title{
Other specifications
}

\section{GIS layers, shapes related to the dataset:}

\author{
species distribution \\ hydrological information (as HydroSHEDS) \\ catchments, river-sub-basins \\ land use \\ dams/reservoirs/barriers \\ protected areas \\ environmental variables (freshwater or terrestrial) \\ no \\ no
}

availability of photos:

availability of maps:

quality control procedures:

Were any quality control procedures applied to your dataset? 


\section{References}

Banarescu, P., 1964. Pisces Osteichthyes. Fauna Republicii Populare Romane. Bucuresti, 963p.

Clesceri, L. S., Greenberg, A. E., Trussell, R. R., (ed.) Crumpton, W. G., Murray, A. P., Paterson, R. A., Sellner, K. G., Suidan, M. T., Sullivan, B. F., Swartz, R., Sweeney, R. A. \& Walsh, G. E. , 1989. Biological examination of water. Part 10000, Standard Methods for the examination of water and waste water 17th Edition. Washington American Public Health Association: 10-194

de Jong, Y. et al. , 2014. Fauna Europaea - all European animal species on the web. Biodiversity Data Journal 2: e4034. http://dx.doi.org/10.3897/BDJ.2.e4034

Froese, R. and Pauly, D. (eds.), 2015. FishBase. World Wide Web electronic publication. www.fishbase.org, version $(04 / 2015)$.

Hanganu, J., Dubyna, D., Zhmud, E., Grigoras, I., Menke, U., Drost, H., Stefan, N. \& Sârbu, I. , 2002. Vegetation of the Biosphere Reserve "Danube Delta" with Transboundary Vegetation Map on a 1: 150000 scale. Danube Delta National Institute, Romania; M.C. Kholodny - Institute of Botany \& Danube Delta Biosphere Reserve, Ukraine and RIZA The Netherlands. RIZA Rapport 2002049, Lelystadt.

Kohler, A., 1978. Methoden der Kartierung von Flora und Vegetation von Süßwasserbiotopen. Landschaft + Stadt 10 (2): 73-85.

Kottelat, M. and Freyhof, J., 2007. European Freshwater Fishes. Kottelat, Cornol, Switzerland and Freyhof, Berlin, Germany. 646p. ISBN 978-2-8399-0298-4. 